\title{
Metal-Free Catalytic Oxidation of Sulfides to Sulfoxides with Ammonium Nitrate, Ammonium Hydrogen Sulfate and Ammonium Bromide as Catalyst
}

\author{
Arash Ghorbani-Choghamarani, ${ }^{*, a}$ Mohammad Ali Zolfigol ${ }^{*, b}$ and Roia Ayazi-Nasrabadi ${ }^{b}$ \\ ${ }^{a}$ Department of Chemistry, Faculty of Science, Ilam University, P.O. Box 69315516, Ilam, Iran \\ ${ }^{b}$ Faculty of Chemistry, Bu-Ali Sina University, P.O. Box 6517838683, Hamadan, Iran
}

A oxidação catalítica geral e sem o uso de metais, de sulfetos alifáticos e aromáticos aos seus sulfóxidos correspondentes via combinação de nitrato de amônio $\left(\mathrm{NH}_{4} \mathrm{NO}_{3}\right)$, hidrogenossulfato de amônio suportado em sílica gel $\left(\mathrm{NH}_{4} \mathrm{HSO}_{4}-\mathrm{SiO}_{2}\right)$ e uma quantidade catalítica de brometo de amônio $\left(\mathrm{NH}_{4} \mathrm{Br}\right)$ na presença de $\mathrm{SiO}_{2}$ aquoso $(50 \%, \mathrm{~m} / \mathrm{m})$ foi investigada. As reações ocorreram em meio heterogêneo e seletivamente em curtos tempos de reação, em $\mathrm{CH}_{2} \mathrm{Cl}_{2}$ a temperatura ambiente. Este procedimento é simples e eficiente comparado a outros métodos relatados.

A general and metal-free catalytic oxidation of aliphatic and aromatic sulfides to their corresponding sulfoxides via combination of ammonium nitrate $\left(\mathrm{NH}_{4} \mathrm{NO}_{3}\right)$, supported ammonium hydrogen sulfate on silica gel $\left(\mathrm{NH}_{4} \mathrm{HSO}_{4}-\mathrm{SiO}_{2}\right)$ and a catalytic amount of ammonium bromide $\left(\mathrm{NH}_{4} \mathrm{Br}\right)$ in the presence of wet $\mathrm{SiO}_{2}(50 \%, \mathrm{w} / \mathrm{w})$ has been investigated. The reactions were carried out heterogeneously and selectively in short reaction times in $\mathrm{CH}_{2} \mathrm{Cl}_{2}$ at room temperature. This protocol is mild and efficient compared to other reported methods.

Keywords: sulfides, sulfoxide, ammonium hydrogen sulfate $\left(\mathrm{NH}_{4} \mathrm{HSO}_{4}\right)$, ammonium nitrate $\left(\mathrm{NH}_{4} \mathrm{NO}_{3}\right)$, ammonium bromide $\left(\mathrm{NH}_{4} \mathrm{Br}\right)$, homoselectivity

\section{Introduction}

The chemoselective oxidation of sulfides to their corresponding sulfoxides is of interest for organic chemists, both for fundamental research and for a variety of applications. Sulfoxides are valuable synthetic intermediates for the synthesis of chemically and biologically significant molecules. ${ }^{1-3}$ Sulfoxides are also valuable materials in $\mathrm{C}-\mathrm{C}$ bond-forming ${ }^{4,5}$ and molecular rearrangements. ${ }^{6-8}$ Additionally some of biologically active sulfoxides play an important role as therapeutic agents such as anti-ulcer, ${ }^{9-11}$ antibacterial, ${ }^{12}$ anti-atherosclerotic, ${ }^{13,14}$ among others. Although a wide variety of oxidizing systems has been applied for the oxidation of sulfides to the sulfoxides such as $\mathrm{H}_{2} \mathrm{O}_{2}$ /silica sulfuric acid, ${ }^{15}$ urea hydrogen peroxide (UHP)/Mn(III), ${ }^{16} \mathrm{Me}-\mathrm{IBX},{ }^{17} \mathrm{H}_{2} \mathrm{O}_{2} /$ $\mathrm{VO}($ acac $){ }_{2},{ }^{18} \mathrm{~N}$-bromosuccinimide, ${ }^{19} \mathrm{H}_{2} \mathrm{O}_{2} / \mathrm{NBS},{ }^{20} \mathrm{H}_{2} \mathrm{O}_{2} /$ $\mathrm{Cr}(\mathrm{III}),{ }^{21}$ 1-benzyl-4-aza-1-azonia-bicyclo[2.2.2] octane tribromide, ${ }^{22} \mathrm{BF}_{4}$-based ionic liquid/UHP, ${ }^{23} \mathrm{H}_{2} \mathrm{O}_{2} / 1,1,1$ trifluoroacetone, ${ }^{24}$ some of these methods still suffer from some drawbacks like overoxidation to sulfones,

*e-mail: arashghch58@yahoo.com; Zolfi@basu.ac.ir low selectivity, low yields of products, tedious work-up, toxicity, and expensive reagents or catalysts.

In the last few years, heterogeneous reagents and catalysts are used increasingly in organic functional group transformation. ${ }^{25-28}$ The development of efficient and new catalytic systems for various organic transformations is an active research area with the aim to develop milder reaction conditions..$^{29}$ Finding molecules which are able to catalyze the reaction between others is an important contribution of molecular chemists to increase the efficiency of chemical reactions whereby our daily life based on consumption of chemicals is shifted closer to an ecologically and economically tolerable equilibrium with our environment. ${ }^{30}$

\section{Results and Discussion}

Recently we have introduced different approaches for the in situ generation of bromonium ion $\left(\mathrm{Br}^{+}\right)$, which effectively applied for the oxidation of different types of organic compounds. ${ }^{31-36}$ In continuation of this investigation we decided to explore catalytic and metal-free media for the in situ generation of $\mathrm{Br}^{+}$. Meanwhile we were interested to use ammonium nitrate $\left(\mathrm{NH}_{4} \mathrm{NO}_{3}\right)$ as very cheap, nontoxic 
and commercially available oxidizing material. Ammonium nitrate is used in fertilizer industry and as an explosive in mining operations. It has been also used widely in different organic transformations such as: cleavage of THP ethers, acetals and acetonides, ${ }^{37}$ nitration of arenes, ${ }^{38}$ dethioacetalization, ${ }^{39}$ coordination of ammonium nitrate to crown ethers. ${ }^{40}$

However, the low oxidizing power of ammonium nitrate is the main drawback to its application. Therefore we decide to activate this reagent with supported ammonium hydrogen sulfate on silica gel $\left(\mathrm{NH}_{4} \mathrm{HSO}_{4}-\mathrm{SiO}_{2}\right)$. Therefore a mixture of $\mathrm{NH}_{4} \mathrm{NO}_{3}, \mathrm{NH}_{4} \mathrm{HSO}_{4}-\mathrm{SiO}_{2}(50 \%$, w/w) and catalytic amounts of $\mathrm{NH}_{4} \mathrm{Br}$ in the presence of wet $\mathrm{SiO}_{2}$ $(50 \%, \mathrm{~m} / \mathrm{m})$, as metal free catalytic media, was combined for the in situ generation of $\mathrm{Br}^{+}$. Consequently, we disclosed a new heterogeneous catalytic protocol for the chemo and homoselective oxidation of sulfides to the sulfoxides using combination of ammonium nitrate, ammonium hydrogen sulfate and wet $\mathrm{SiO}_{2}(50 \%, \mathrm{w} / \mathrm{w})$ in the presence of catalytic amounts of $\mathrm{NH}_{4} \mathrm{Br}$.

Obviously, solvent plays an important role in organic transformations, and hence it was decided to investigate the solvent effect and also find an appropriate solvent for the oxidation of sulfides. However, we screened different solvents for the oxidation of dibenzyl sulfide, as a typical example. The oxidation of dibenzyl sulfide was carried out using a mixture containing $1 \mathrm{mmol}$ of dibenzyl sulfide, $\mathrm{NH}_{4} \mathrm{NO}_{3}$ (1.2 mmol), $\mathrm{NH}_{4} \mathrm{HSO}_{4}-\mathrm{SiO}_{2}\left(50 \%\right.$, w/w) (1.2 mmol), $\mathrm{NH}_{4} \mathrm{Br}$ $(0.02 \mathrm{mmol})$ and $0.2 \mathrm{~g}$ of wet $\mathrm{SiO}_{2}(50 \%, \mathrm{w} / \mathrm{w})$ in $5 \mathrm{~mL}$ of solvent at room temperature. As is evident from Table 1 oxidation reaction proceeds more rapidly and more selectively in dichloromethane compared to other solvents.

Eventually, we wish to report here the selective oxidation of wide range of aliphatic and aromatic sulfides $\mathbf{1}$ to the corresponding sulfoxides 2 using $\mathrm{NH}_{4} \mathrm{NO}_{3}$ I, supported
Table 1. Oxidation of dibenzyl sulfide using $\mathrm{NH}_{4} \mathrm{NO}_{3}, \mathrm{NH}_{4} \mathrm{HSO}_{4}-\mathrm{SiO}_{2}$ $(50 \%, \mathrm{w} / \mathrm{w})$ and catalytic amounts of $\mathrm{NH}_{4} \mathrm{Br}$ in the presence of wet $\mathrm{SiO}_{2}$ $(50 \%, \mathrm{w} / \mathrm{w})$ in different solvents at room temperature ${ }^{\mathrm{a}}$

\begin{tabular}{lccc}
\hline Entry & Solvent & time / min & Yield / $(\%)^{\mathrm{b}}$ \\
\hline 1 & Acetonitrile & 30 & 98 \\
2 & Acetone & 480 & $--^{\mathrm{c}}$ \\
3 & Chloroform & 35 & 90 \\
4 & Dichloromethane & 20 & 98 \\
5 & $n$-Hexane & 162 & $--^{\mathrm{d}}$ \\
6 & Ethanol & 480 & $--^{\mathrm{c}}$ \\
7 & Methanol & 480 & $--^{\mathrm{c}}$ \\
8 & Ethyl acetate & 80 & 96 \\
\hline
\end{tabular}

a Substrate : $\mathrm{NH}_{4} \mathrm{NO}_{3}: \mathrm{NH}_{4} \mathrm{HSO}_{4}-\mathrm{SiO}_{2}: \mathrm{NH}_{4} \mathrm{Br}$ : wet $\mathrm{SiO}_{2}=1 \mathrm{mmol}$ : $1.2 \mathrm{mmol}: 1.2 \mathrm{mmol}: 0.02 \mathrm{mmol}: 0.2 \mathrm{~g}$. ${ }^{\mathrm{b} I s o l a t e d}$ yield. ${ }^{\mathrm{c}}$ No reaction. ${ }^{\mathrm{d}}$ Reaction was complete but impurity of sulfone was observed.

ammonium hydrogen sulfate on silica $\left[\mathrm{NH}_{4} \mathrm{HSO}_{4}-\mathrm{SiO}_{2}\right.$ $(50 \%, w / w)]$ II and catalytic amounts of $\mathrm{NH}_{4} \mathrm{Br}$ III in the presence of wet $\mathrm{SiO}_{2}(50 \%$, w/w) in dichloromethane at room temperature with good to excellent yields (Scheme 1 and Table 2).

$\mathrm{NH}_{4} \mathrm{Br}$ is the catalytic part of this oxidizing system. Therefore to investigate the catalytic role of $\mathrm{NH}_{4} \mathrm{Br}$ dibenzyl sulfide was subjected to the oxidation reaction in the absence of catalyst. However, no sulfoxide was observed after $3 \mathrm{~h}$ (Table 1, entry 4). Also the necessity of wet $\mathrm{SiO}_{2}(50 \%$, w/w), as source of water, and $\mathrm{NH}_{4} \mathrm{HSO}_{4}-\mathrm{SiO}_{2}(50 \%$, w/w) were considered. Therefore to show the role of supported ammonium hydrogen sulfate on silica in this system, oxidation of dibenzyl sulfide was carried out in the absence of this reagent. Interestingly it was observed that the reaction did not proceed in the absence of $\mathrm{NH}_{4} \mathrm{HSO}_{4}-\mathrm{SiO}_{2}$ (Table 1, entry 5). Also is evident from entry 6 of Table 1, that wet $\mathrm{SiO}_{2}$ is necessary for the described system.

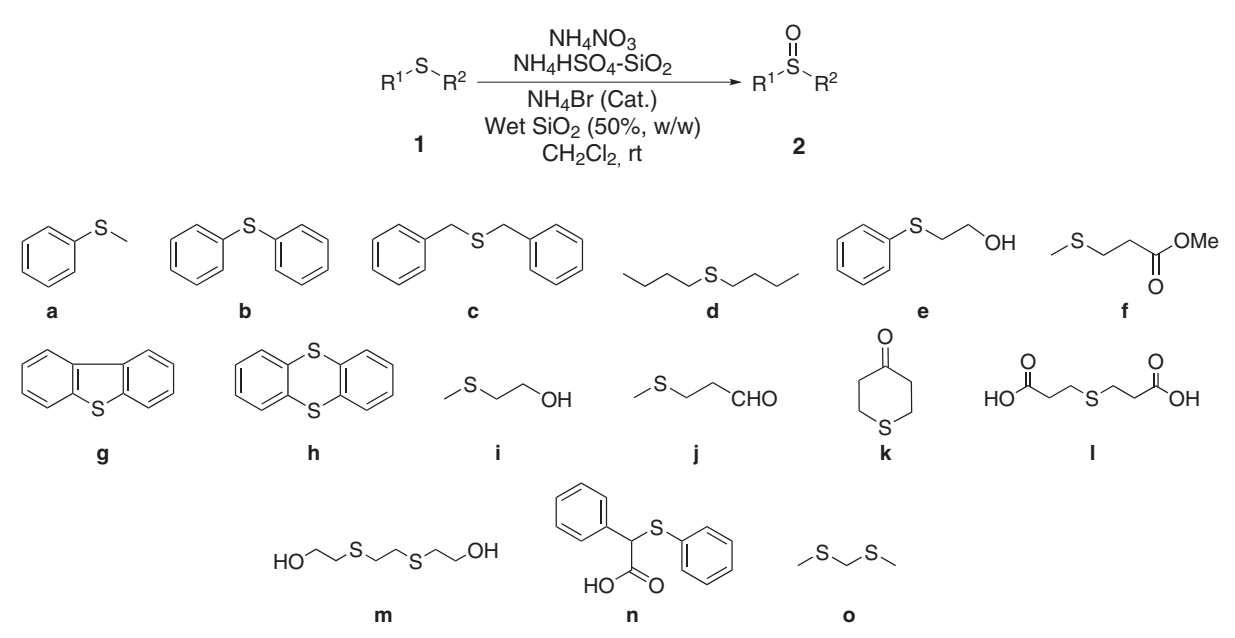

Scheme 1. Catalytic oxidation of sulfides to the corresponding sulfoxides. 
Table 2. Oxidation of sulfides 1 to the corresponding sulfoxides 2 using $\mathrm{NH}_{4} \mathrm{NO}_{3}$ (I), $\mathrm{NH}_{4} \mathrm{HSO}_{4}-\mathrm{SiO}_{2}(50 \%$, w/w), (II) and catalytic amounts of $\mathrm{NH}_{4} \mathrm{Br}$ (III) in the presence of wet $\mathrm{SiO}_{2}(50 \%$, w/w) in dichloromethane at room temperature

\begin{tabular}{|c|c|c|c|c|c|c|c|}
\hline \multirow{2}{*}{ Entry } & \multirow{2}{*}{ Substrate } & \multirow{2}{*}{ Product } & \multicolumn{3}{|c|}{$\begin{array}{c}\text { Substrate/Reagents/ } \\
\text { Catalyst } / \mathrm{mmol}^{\mathrm{a}}\end{array}$} & \multirow{2}{*}{$\begin{array}{c}\text { time / } \\
\text { min }\end{array}$} & \multirow{2}{*}{$\begin{array}{c}\text { Yield } \\
(\%)^{\mathrm{b}}\end{array}$} \\
\hline & & & I & II & III & & \\
\hline 1 & 1a & $2 a$ & 1.2 & 1.2 & 0.02 & 25 & 85 \\
\hline 2 & $1 b$ & $2 b$ & 2 & 2 & 0.15 & $48 \mathrm{~h}$ & $70 c$ \\
\hline 3 & $1 c$ & $2 c$ & 1.2 & 1.2 & 0.02 & 20 & 98 \\
\hline 4 & $1 c$ & $2 c$ & 1.2 & 1.2 & --- & 180 & $--d, e$ \\
\hline 5 & 1c & $2 c$ & 1.2 & --- & 0.02 & 180 & $--e, f$ \\
\hline 6 & $1 c$ & $2 c$ & 1.2 & 1.2 & 0.02 & 180 & $--\mathrm{e}, \mathrm{g}$ \\
\hline 7 & 1d & 2d & 1.2 & 1.2 & 0.02 & 20 & 86 \\
\hline 8 & $1 e$ & $2 e$ & 1.5 & 1.5 & 0.1 & 165 & 96 \\
\hline 9 & 1f & $2 f$ & 1.2 & 1.2 & 0.02 & 15 & 98 \\
\hline 10 & $1 \mathrm{~g}$ & $2 g$ & 1.2 & 1.2 & 0.02 & 50 & 93 \\
\hline 11 & 1h & $2 h$ & 2 & 2 & 0.1 & $26 \mathrm{~h}$ & 99 \\
\hline 12 & $1 \mathrm{i}$ & $2 \mathrm{i}$ & 1.2 & 1.2 & 0.02 & 60 & 86 \\
\hline 13 & $\mathbf{1 j}$ & $2 j$ & 1.2 & 1.2 & 0.02 & 20 & 73 \\
\hline 14 & $1 \mathrm{k}$ & $2 \mathrm{k}$ & 1.2 & 1.2 & 0.02 & 35 & 98 \\
\hline 15 & 11 & 21 & 1.2 & 1.2 & 0.02 & 15 & 45 \\
\hline 16 & $1 \mathrm{~m}$ & $2 m$ & 1.2 & 1.2 & 0.02 & 180 & 20 \\
\hline 17 & 1n & $2 n$ & 1.2 & 1.2 & 0.02 & 10 & 85 \\
\hline 18 & 10 & 20 & 1.2 & 1.2 & 0.02 & 40 & 98 \\
\hline
\end{tabular}

a Substrate : wet $\mathrm{SiO}_{2}=1 \mathrm{mmol}: 0.2 \mathrm{~g}$. ${ }^{\mathrm{b}}$ Isolated yield. ${ }^{\mathrm{c}} \mathrm{GC}$ yield. ${ }^{\mathrm{d} I n}$ the absence of $\mathrm{NH}_{4} \mathrm{Br}$. ${ }^{\mathrm{e}} \mathrm{No}$ reaction. ${ }^{\mathrm{f} I n}$ the absence of $\mathrm{NH}_{4} \mathrm{HSO}_{4}-\mathrm{SiO}_{2} \cdot{ }^{\mathrm{g}} \mathrm{In}$ the absence of wet $\mathrm{SiO}_{2}$.

It is of interest to note that the mentioned oxidizing system allowed the homoselective ${ }^{31,33}$ oxidation of thianthrene and bis-(methyl thio)-methane to their monosulfoxide derivatives (Scheme 2, entries 11 and 18).

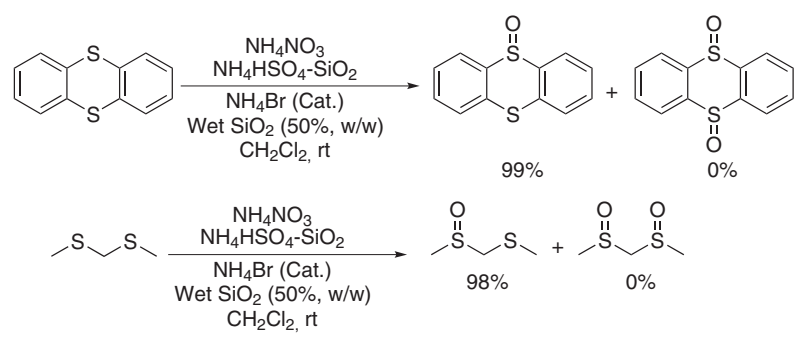

Scheme 2. Homoselective oxidation of thianthrene and bis-(methyl thio)methane to their monosulfoxide derivatives.

Finally to show the chemoselectivity of the described system, two sulfides containing a hydroxy group were subjected to the sulfoxidation reaction, but alcohol oxidation did not occur under mentioned conditions, and primary hydroxyl group remained intact in the course of the reaction (Table 2, entries 8 and 12, Scheme 3).

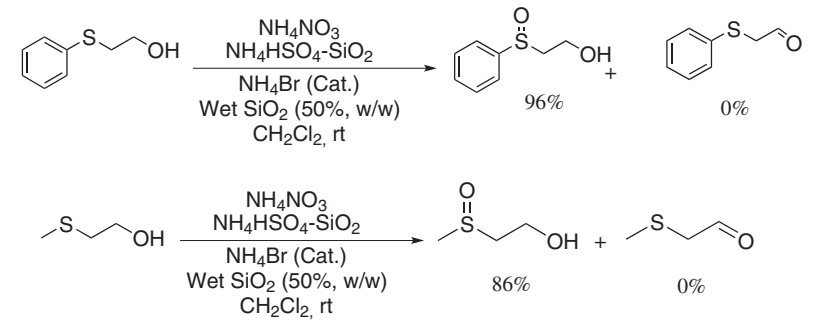

Scheme 3. Chemoselective sulfoxidation of 2-(phenylthio) ethanol and 2-(metylthio) ethanol.

A possible mechanism of this oxidizing system is shown in Scheme 4 based on our previously reported works. ${ }^{31-36}$

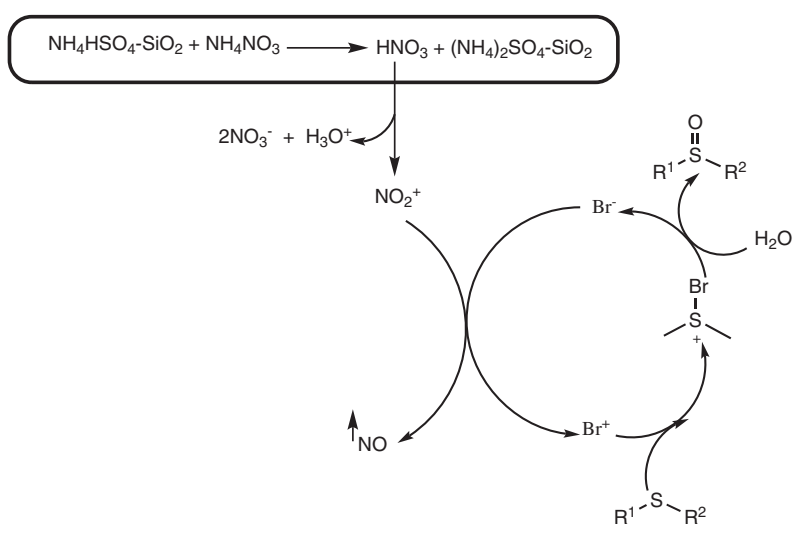

Scheme 4. General mechanism for the oxidation of sulfides to the sulfoxides.

In the first place, $\mathrm{NH}_{4} \mathrm{NO}_{3}$ reacts with $\mathrm{NH}_{4} \mathrm{HSO}_{4}$ to produce in situ $\mathrm{HNO}_{3}$. Subsequently, auto ionization of $\mathrm{HNO}_{3}$ generates nitronium ion $\left(\mathrm{NO}_{2}^{+}\right)$, which is able to convert bromide ion $\left(\mathrm{Br}^{-}\right)$to bromonium $\left(\mathrm{Br}^{+}\right)$. In the last step reaction of bromonium ion with sulfide in the presence of water might generate the corresponding sulfoxide.

In summary herein we report a novel catalytic protocol for the chemo and homoselective oxidation of sulfides to the sulfoxides under metal-free, mild and heterogeneous conditions. This method offers the advantage of shorter reaction times, high selectivity, non toxic conditions, cost effective reagents and catalyst and easy workup. We believe that the present methodology could be an important addition to the existing methodologies.

\section{Experimental}

Chemicals were purchased from Fluka, Merck and Aldrich chemical companies. The oxidation products were characterized by comparison of their spectral (IR, ${ }^{1} \mathrm{H}$ NMR, and ${ }^{13} \mathrm{C}$ NMR) and physical data with authentic samples. 
Oxidation of dibenzyl sulfides $\mathbf{1 c}$ to dibenzyl sulfoxide $\mathbf{2 c}$ using $\mathrm{NH}_{4} \mathrm{NO}_{3}, \mathrm{NH}_{4} \mathrm{HSO}_{4}-\mathrm{SiO}_{2}$ and $\mathrm{NH}_{4} \mathrm{Br}$ as a typical procedure

$\mathrm{NH}_{4} \mathrm{NO}_{3}(0.096 \mathrm{~g}, 1.2 \mathrm{mmol}), \mathrm{NH}_{4} \mathrm{Br}(0.0019 \mathrm{~g}$, $0.02 \mathrm{mmol}), \mathrm{NH}_{4} \mathrm{HSO}_{4}-\mathrm{SiO}_{2}(50 \%$, w/w $),(0.276 \mathrm{~g}$, $1.2 \mathrm{mmol})$ and $0.2 \mathrm{~g}$ of wet $\mathrm{SiO}_{2}(50 \%$, w/w) were added to a solution of dibenzyl sulfide $1 \mathrm{c}(0.214 \mathrm{~g}, 1 \mathrm{mmol})$ in $\mathrm{CH}_{2} \mathrm{Cl}_{2}(5 \mathrm{~mL})$. The resulting mixture was stirred at room temperature for $20 \mathrm{~min}$ (the reaction progress was monitored by TLC) and then filtered. The residue was washed with $\mathrm{CH}_{2} \mathrm{Cl}_{2}(4 \times 5 \mathrm{~mL})$. Anhydrous $\mathrm{Na}_{2} \mathrm{SO}_{4}(1.5 \mathrm{~g})$ was added to the filtrate and filtered off after $20 \mathrm{~min}$. Finally $\mathrm{CH}_{2} \mathrm{Cl}_{2}$ was removed and the yield was $0.221 \mathrm{~g}(98 \%)$.

\section{Acknowledgments}

Financial support for this work by the Center of Excellence of Development of Chemical Methods (CEDCM) of Bu-Ali Sina University, Hamadan, Iran is gratefully acknowledged.

\section{References}

1. Hiroi, K.; Suzuki, Y.; Abe, I.; Kawagishi, R.; Tetrahedron 2000, $56,4701$.

2. Carreno, M. C.; Chem. Rev. 1995, 95, 1717.

3. Fernandez, I.; Khiar, N.; Chem. Rev. 2003, 103, 3651.

4. Satoh, T.; Kuramochi, Y.; Inoue, Y.; Tetrahedron Lett. 1999, 40, 8815 .

5. Kosugi, H.; Watanabe, Y.; Uda, H.; Chem. Lett. 1989, 1865.

6. Christov, V. C.; Ivanov, I. K.; Synth. Commun. 2004, 34, 3963.

7. Aoyagi, S.; Makabe, M.; Shimada, K.; Takikawa, Y.; Kabuto, C.; Tetrahedron Lett. 2007, 48, 4639.

8. Shainyan, B. A.; Kirpichenko, S. V.; Freeman, F.; J. Am. Chem. Soc. 2004, 126, 11456.

9. Mc, T. D.; Buckley, M. M.; Heel, R. C.; Drugs 1991, 1, 138.

10. Okabe, S.; Shimosako, K.; J. Physiol. Pharmacol. 2001, 52, 639.

11. Spencer, C. M.; Faulds, D.; Drugs 2000, 60, 321.

12. Prilezhaeva, E. N.; Russ. Chem. Rev. 2001, 70, 897.

13. Perez-Giraldo, C.; Cruz-Villalon, G.; Sanchez-Silos, R.; Martinez-Rubio, R.; Blanco, M. T.; Gomez-Garcia, A. C.; J. Appl. Microbiol. 2003, 95, 709.

14. Yoshida, S.; Kasuga, S.; Hayashi, N.; Ushiroguchi, T.; Matsuura, H.; Nakagawa, S.; Appl. Environ. Microbiol. 1987, 53, 615.

15. Shaabani, A.; Rezayan, A. H.; Catal. Commun. 2007, 8, 1112.

16. Bagherzadeh, M.; Tahsini, L.; Latifi, R.; Catal. Commun. 2008, 9, 1600.

17. Moorthy, J. N.; Singhal, N.; Senapati, K.; Tetrahedron Lett. 2008, 49,80 .
18. Prasanth, K. L.; Maheswaran, H.; J. Mol. Catal. A: Chem. 2007, $268,45$.

19. Ali, M. H.; Hartman, M.; Lamp, K.; Schmitz, C.; Wencewicz, T.; Synth. Commun. 2006, 36, 1769.

20. Karimi, B.; Zareyee, D.; J. Iran. Chem. Soc. 2008, 5, S103.

21. Supale, A. R.; Gokavi, G. S.; Catal. Lett. 2008, 124, 284.

22. Pourmousavi, S. A.; Salehi, P.; Bull. Korean Chem. Soc. 2008, 29, 1332.

23. Palombi, L.; Bocchino, C.; Caruso, T.; Villano, R.; Scettri, A.; Tetrahedron Lett. 2008, 49, 5611.

24. Lupattelli, P.; Ruzziconi, R.; Scafato, P.; Degl'Innocenti, A.; Paolobelli, A. B.; Synth. Commun. 1997, 27, 441.

25. Tapia, R.; Torres, G.; Valderrama, J. A.; Synth. Commun. 1986, 16, 681.

26. Shirini, F.; Zolfigol, M. A.; Torabi, S.; Lett. Org. Chem. 2005, 2,760 .

27. Zolfigol, M. A.; Shirini, F.; Ghorbani-Choghamarani, A.; Mohamadpoor-Baltork, I.; Green Chem. 2002, 562.

28. Zolfigol, M. A.; Bagherzadehb, M.; Niknam, K.; Shirini, F.; Mohammadpoor-Baltork, I.; Ghorbani-Choghamarani, A.; Baghbanzadeh M.; J. Iran. Chem. Soc. 2006, 3, 73.

29. Nandurkar, N. S.; Bhanushali, M. J.; Bhor, M. D.; Bhanage, B. M.; J. Mol. Catal. A: Chem. 2007, 271, 14.

30. Togni, A.; Grützmacher, H.; Catalytic Heterofunctionalization, Wiley-VCH Verlag GmbH: Weinheim, 2001.

31. Zolfigol, M. A.; Amani, K.; Hajjami, M.; GhorbaniChoghamarani, A.; Ayazi-Nasrabadi, R.; Jafari, S.; Catal. Commun. 2008, 9, 1739.

32. Zolfigol, M. A.; Amani, K.; Hajjami, M.; GhorbaniChoghamarani, A.; Monatsh. Chem. 2008, 139, 895.

33. Zolfigol, M. A.; Amani, K.; Ghorbani-Choghamarani, A.; Hajjami, M.; Monatsh. Chem. 2009, 140, 65.

34. Zolfigol, M. A.; Shirini, F.; Ghorbani-Choghamarani, A.; Synthesis 2006, 2043.

35. Zolfigol, M. A.; Bagherzadeh, M.; Mallakpour, S.; Chehardoli, G.; Kolvari, E.; Ghorbani-Choghamarani, A.; Koukabi, N.; Catal. Commun. 2007, 8, 256.

36. Zolfigol, M. A.; Bagherzadeh, M.; Mallakpour, S.; Chehardoli, G.; Ghorbani-Choghamarani, A.; Koukabi, N.; Dehghanian, M.; Doroudgar, M.; J. Mol. Catal. A: Chem. 2007, 270, 219.

37. Meshram, H. M.; Sumithra, G.; Reddy, G. S.; Ganesh, Y. S. S.; Yadav, J. S.; Synth. Commun. 1999, 29, 2807.

38. Meshram, H. M.; Ganesh, Y. S. S.; Madhavi, A. V.; Eshwaraiah, B.; Yadav, J. S.; Gunasekar, D.; Synth. Commun. 2003, 33, 2497.

39. Meahram, H. M.; Reddy, G. S.; Yadav, J. S.; Tetrahedron Lett. 1997, 38, 8891.

40. Doxsee, K. M.; Jr, P. E. F.; Weakley, T. J. R.; Tetrahedron 2000 , 56,6683 .

Received: February 19, 2009 Web Release Date: October 9, 2009 